\title{
UN LARGO ADIÓS AL MAESTRO Y AMIGO
}

\author{
Julián Meza*
}

Conocí a Luis Astey hace casi veinte años, cuando ingresé como profesor de tiempo completo en el Departamento de Estudios Generales del ITAM. Lo vi por primera vez al iniciarse una de esas reuniones académicas en las que coincidiríamos por espacio de muchos años. Fuimos presentados por el maestro José Ramón Benito, jefe del Departamento. Durante la presentación fuimos parcos, gracias a él, pues no permitió que lo indigestara con más de diez palabras. En el transcurso de esa misma reunión me llamaron poderosamente la atención su silencio y su sonrisa, sobre todo su sonrisa, que no era precisamente complaciente, ya que el brillo de sus ojos me alertaba sobre algo que sólo advertí más tarde, cuando descubrí que, sin ser Marcel Pagnol o Voltaire, era yo demasiado parlanchín.

Toé, pintor y dibujante, que durante mucho tiempo fue el jefe de publicidad de Marcel Pagnol y el realizador de los carteles de sus películas, recuerda haber encontrado a Albert Cohen en compañia de Pagnol en el París de los años treinta, y los describe así:

Marcel Pagnol y Albert Cohen intercambiaban recuerdos. Pagnol era el parlanchín. Tenía el genio del diálogo (que yo no tengo). Cohen escuchaba, como todo el mundo, a ese Pagnol, que era un hombre encantador. Mi primera reacción frente a Cohen fue la sorpresa: creía que era un marsellés, que hablaba

* Departamento Académico de Estudios Generales, ITAM. 
JULIÁN MEZA

alto y fuerte, pero era un hombre dulce, un tímido que escuchaba. Tenía una silueta con la espalda ligeramente curvada, que probablemente sabía lo que valía sin dejar de ser modesto. No era un adulador. Era reservado, replegado sobre sí mismo. Lo que me sorprendió siempre en él fue ver a un hombre tan tímido, tan replegado sobre sí mismo, que tenía una enorme fuerza en la escritura, a la manera del dibujante Dubout...

Al igual que Albert Cohen, Luis Astey era una especie de corfiota judío convertido al románico, un europeo, un mediterráneo silencioso que no ignoraba su valía, pero que jamás trataba de demostrarla. De la misma manera que Albert Cohen, Luis Astey era un hombre dulce, un hombre tímido que escuchaba, aun cuando quien le hablara no valiese un comino. A semejanza de Cohen tenía la espalda ligeramente curvada, y el gran filólogo que fue igualó y aun superó en modestia al gran novelista que era Cohen. Jamás le oí hablar de su obra, ni menos aún de sus proezas lingüísticas y filológicas, que son magistrales. Quien no lo haya conocido a fondo puede pensar que carecía de opinión frente a los numerosos temas que los demás humanos abordamos casi

134 siempre sin conocimiento de causa, salpicados de opiniones en general insignificantes. Su repliegue sobre sí mismo era tal vez el resultado, temprano, de su experiencia en el mundo, que ciertamente valía una fortuna, y mucho más que todas las fortunas amasadas en México a lo largo de este siglo. Ese tímido, ese hombre replegado sobre sí mismo era, entonces, un hombre de una fortaleza inquebrantable, y no sólo en el dominio de la filología y la escritura. Luis Astey fue un hombre poderosamente vital. $Y$ aquí vuelvo al tema de su sonrisa y al brillo de sus ojos. Hago la analogía de Luis Astey con Albert Cohen y Voltaire porque al igual que ese magnífico escritor de orígenes un tanto imprecisos de tan precisos y ese filósofo tan filosófico, lo que más despreciaba Luis Astey era la imbecilidad humana, tan generalizada en nuestro tiempo. En este sentido al igual que Flaubert y Cohen, Astey era un auténtico discípulo de Voltaire. Pero la genealogía de Luis Astey hunde también sus raíces en otros momentos de ese remoto 
UN LARGO ADIÓS

tiempo europeo, dado que su sonrisa y su mirada también remiten a Diderot, cuyas breves frases y fulminantes sonrisas eran más demoledoras que un 14 de julio de 1789 en la Bastilla. Más aún, sus escasas palabras son herederas de Rabelais, pues su sentido del humor (tan escaso entre nosotros) era inigualable. Sé muy bien que el tiempo de Luis Astey es, en buena medida, un tiempo anterior al de la modernidad europea, que remite, en términos generales, a los orígenes de la civilización occidental y, en términos particulares, a los orígenes de nuestra lengua, pero siempre supo ir más allá y, al mismo tiempo, ser tan moderno como Joyce, Proust, Kafka o Albert Cohen.

La muerte de Luis Astey es una pérdida dolorosa para la comunidad académica, intelectual y literaria mexicana. También lo es para la selecta comunidad internacional a la que perteneció, discretamente, tan discretamente como sólo pueden formar parte de ella los sabios, a la manera de Luis Astey, a quien hoy rindo homenaje como maestro (que formalmente nunca lo fue, aunque siempre me enseñó mucho más que muchos de mis maestros), y como amigo, cuyo valor será siempre inagotable.

Quiero concluir citando unos versículos del "Eclesiastés" que yo, profano, no puedo comentar como lo hizo, con sabiduría e imaginación, Luis Astey, pero me basta con citarlos como homenaje a la humildad del maestro y el amigo:

Capítulo I, versículos 1 a 6 :

1. Las palabras del Eclesiastés, hijo de David y rey de Jerusalén.

2. Vanidad de vanidades, dice el Eclesiastés, vanidad de vanidades, todo es vanidad.

3. ¿Qué obtiene el hombre de todo el trabajo que lo ocupa bajo el sol?

4. Una raza pasa, otra la sigue, pero la tierra permanece firme para siempre.

5. El sol se levanta y se acuesta, y vuelve a donde partió, y renace en el mismo lugar. 
JULIÁN MEZA

6. Toma su curso hacia el mediodía y vuelve hacia el Norte. El espíritu remolinea por todas partes, y vuelve sobre sí mismo a través de largos circuitos.

Luis Astey sabía que, en el fondo, todo era vanidad; por eso fue humilde. Y, sin embargo, era como el sol, que tomó su curso hacia el Mediodía mediterráneo (románico en particular) y volvió hacia el Norte brumoso en donde habitamos y, como el espíritu, hoy vuelve sobre sí mismo a través de nosotros, sus discípulos, sus amigos, que lo extrañaremos como sólo se extraña a los verdaderos maestros y amigos.

Sin lugar a dudas, Luis Astey descansa en paz y todavía sigue riéndose de nosotros, y con razón, pues sólo le podemos ofrecer el triste espectáculo de nuestra melancolía, en la que ya no nos acompaña con su sonrisa y sus breves comentarios. 